\title{
Editorial: Balanced Politics
}

'The primary and, in the last resort, the only object of every political party is its own growth, and that without limit.' Simone Weil (for it is she) is perhaps not quite right. The first (and last) object of every political party is power, and in pursuit of that, and of (as she says) 'manufacturing collective passion' (and so drowning out individual thought and voice), all kinds of strange things happen.

In the recent British general election, we have had Conservatives campaigning for Change (their capital) and what they called the Big Society, without any hint of shame or embarrassment (and we don't think they just meant a change of government). We have had the Labour (or socialist) party advocating a new nuclear deterrent and foreign wars, after a decade or more of cosseting big business. And the Liberal Democrats want to nationalise failing banks, forcibly to split up the operations of all banks and to set up a new state bank to direct spending towards its favoured and centrally determined projects.

It could be argued that any or all of these policies are reasonable. The point is that each seems at the very least in tension with the basic motivation of the political party in question. So what, other than a mechanism for its own growth, is the point of a political party? Supporters and voters apparently simply have to grin and bear the advocacy of the very policies they might have thought they were against, and the abandonment of causes they hold dear. Many do, of course, because of the old atavistic lust for power. Others, on the other hand, give up in despair, feeling that their views are not represented at all, particularly when, as happens more often than it might seem on the surface, all major parties are in agreement, and dissent is drowned out.

We heard a lot in the 2010 election campaign about the virtues and defects of 'hung' or 'balanced' parliaments (hung or balanced, depending on one's stance here). The main objection to a hung parliament is that it will involve horse-trading, 'messy' compromises and sordid lobbying for power, as if such behaviour was not already the norm within political parties, and as if political parties ever did anything other than seek their own power and growth. (And, to add insult to injury, in the wake of a slew of scandals relating to political funding and politician's expenses, in Britain they now have the cheek to ask us all to fund them centrally through taxation.) 


\section{Editorial}

The article from which Simone Weil's remarks were taken was entitled 'For the General Suppression of Political Parties'. Sixty seven years after its composition it seems quite a good idea. Maybe - even reflecting on how they did things in ancient Athens - political philosophers could think of the mechanisms and feasibility of a fluid democratic politics without political parties. 